\title{
骨折を伴う外固定が関節拘縮と廃用性筋萎縮に及ぼす影響
}

\author{
西川 彰1,2, 西尾 俊亮 ${ }^{2}$, 西川 晃子 ${ }^{2}$, 今北 英高 $^{2}$
}

\section{The effects of fracture fixation on joint contracture and disuse atrophy in immobilized rat soleus muscle}

\author{
Akira Nishikawa $^{1,2}$, Shunsuke Nishio ${ }^{2}$, Akiko Nishikawa ${ }^{2}$ and Hidetaka Imagita ${ }^{2}$ \\ 1帝京平成大学地域医療学部，テ290-0193 千葉県市原市うるいど南4-1 (Faculty of Regional Health Therapy, Teikyo \\ Heisei University, 4-1 Uruidominami, Ichihara-City, Chiba 290-0193, Japan) \\ 2 畿央大学大学院健康科学研究科, $\overline{\mathbf{T}} 635-0832$ 奈良県北暮城郡広陵町馬見中4-2-2 (Health Sciences Major, Graduate \\ School of Health Sciences, Kio University, 4-2-2 Umami-naka, Koryo-cho, Kitakatsuragi-gun, Nara 635-0832, Japan)
}

Received: December 23, 2010 / Accepted: October 6, 2011

\begin{abstract}
In the present study, we investigated the effects of fracture fixation on joint contracture and disuse muscle atrophy. We surgically fractured the right hind limbs of male Wistar rats, and then fixed the right ankle joints at maximal plantar flexion for two weeks using dorsal splints. Compared with immobilized healthy and sham operated joints, the fractured joints concomitantly showed highly restricted range of motion and significantly higher degrees of disuse atrophy in soleus muscle; decrease of muscle fiber cross sectional area, development of central core lesion and a change in myosin heavy chain isoforms from slow type myosin to fast type myosin. Therefore, it is suggested that orthopedic fracture fixation induces intense disuse muscle atrophy to aggravate joint contracture.
\end{abstract}

Jpn J Phys Fitness Sports Med, 61(1): 95-101 (2012)

Keywords : soleus muscle, fracture fixation, disuse atrophy, range of motion

\section{背 景}

関節拘縮（関節可動域制限）の分類に関しては，その 原因となる病変部位を基に(1)関節性（勒带損傷や関節の 不適合性，滑膜や線維脂肪組織増殖，関節線維症），(2) 軟部組織性（関節周囲軟部組織，皮膚や皮下組織，腱や 勒带)，(3)筋性（内因性としての外傷や炎症，変性，虚 血, 外因性としての痤性や弛緩性麻痺など）の 3 種類が 一般的である (HalarとBellの分類 $)^{1)}$. 整形外科領域に 扔ける外傷性疾患に対して, 関節を固定することで発生 する関節拘縮には，これら 3 つの要因が複合的に関与し ていると考えられる，実験動物を用いたこれまでの研究 において，ギプス固定などにより関節を不動化すると， 短期間（1 ケ月以内）の場合では関節拘縮の責任病巣と しては骨格筋の関与率が最も大きく, 長期に及ぶほど皮 虐, 関節包, 勒带といった骨格筋以外の組織の影響が大 きくなってくることが明らかとなっている2)。また，尙 髄損傷ラットを用いたMoriyamaら ${ }^{3)}$ の報告では, 関節 拘縮の発生初期では骨格筋の関与率は小さいが, 拘縮が 進行するにつれてその率は大きくなっていくとされてい る。このことから，関節拘縮の発生原因の違いによりそ
の進行過程も異なることが予測されるが，その発生に影 響を与える因子としての骨格筋の関与は何れにせよ大き いものと考えられる.

関節拘縮の発生時に起こる廃用性筋萎縮については, 様々な分析方法によりその特性が調べられている，短縮 位で固定したヒラメ筋では, type I 線維, type II 線維と もに筋線維横断面積は減少するが，その反面，筋内の結 合組織(筋周膜や筋内膜) は増加することが明らかとなっ ている ${ }^{4,5)}$ 。また, 萎縮した骨格筋の微細構造を電子顕 微鏡を用いて観察した研究では，筋節数が減少すること で筋長が短縮すること，筋原線維の配列の乱れやZ帯の 蛇行などの構造的変化が起こることなども報告されてい $る^{6,7)}$. 一方, 筋萎縮が進行するとミオシン重鎖アイソ フォームのタイプ変化や筋小胞体機能の変化, コラーゲ ン線維の配列変化なども起こるとされているが8-10)，そ れらが収縮張力などの筋張力特性の変化にも影響を与え ていると考えられる。

以上のように，関節を不動化することで発生する関節 拘縮やそれに関連する骨格筋の退行性変化に関する研究 は数多く行われているが，そのほとんどは健常な関節部 を人工的に固定（内固定または外固定）した実験手法を 
用いたものであり，運動器の外傷性疾患（骨折など）に 対する治療過程において発生した関節拘縮や廃用性筋萎 縮を対象とした研究はほとんど行われていないといえ る。そのため, 本研究では外科的骨折処置を施した骨折 治療モデルラットを作成し，その治療過程で発生する関 節拘縮と廃用性筋萎縮の病態について調査することとし た.

\section{対象と方法}

対象動物 実験動物には10週齢のWistar系雄性ラッ 卜24匹（体重254.3 $\pm 11.5 \mathrm{~g}$ ）を使用し，無作為に対照群 (control group ; Con, n=6), 非骨折群 (non-fracture group ; NFr, $\mathrm{n}=6$ ), シャム群 (sham group; $\mathrm{Sh}, \mathrm{n}=6$ ), 骨折群（fracture group；Fr, n=6）の 4 群に分類した. Con群は無処置とし，NFr群には外固定のみ, Sh群に は皮膚と筋膜を切開しただけの偽手術と外固定，Fr群 には外科的骨折手術と外固定の処置をそれぞれ行った。 Con群とNFr群間から固定の影響を，NFr群とSh群間か らは手術侵襲の影響を, Sh群とFr群間からは骨折の影 響を比較検討することとした。

尚, 本実験は畿央大学動物実験倫理委員会の承認を得 て, 畿央大学動物実験管理規定に従い行った（承認番号 21-7-I-210824)

外科的骨折手術 ペントバルビタールナトリウムを腹腔 内投与 $(50 \mathrm{mg} / \mathrm{kg} \cdot$ body weight）した麻酔下において, ラットの右下腿前面の皮膚並びに筋膜を切開し脛骨を露 出させた，その状態でエレバトリウム（陶芸用の線描き ベラを代用)を脛骨の外側縁と前脛骨筋の間から刺入し, 脛骨後方を通って内側へと貫通させ，周囲の骨格筋を損 傷させないように注意しながら骨切り鋏を用いて, 脛骨 骨幹部が横骨折となるよう切断した。 その後, 皮虐を縫 合してから両骨折端が接合するよう整復操作を行った (Fig 1).

外固定法 熱可塑性硬性固定材料（イワツキ, レナサー ム）を用いて，膝関節軽度屈曲位（約 $30^{\circ} ）$, 足関節最大 底屈位で大腿遠位部から足部までの背側面にシーネを当 て, 同時に 3 箇所（大腿下部，下腿下部，足部）でシー ネと下肢を 2 週間固定した。尚，固定材料がラットに よって噛み切られるのを防ぐため, 針金を編んで作製し

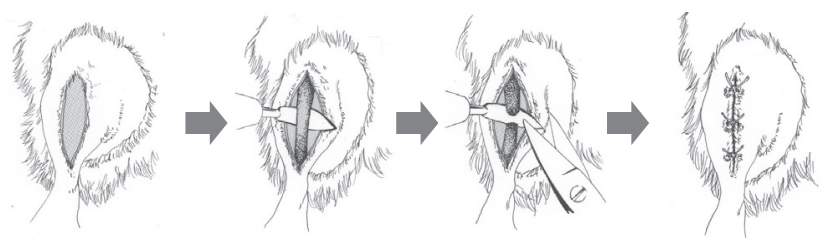

Fig 1. Surgical operation procedure (self-created illustrations)
たソケット状の金具を右後肢全体に被せた（Fig 2)。山 本ら ${ }^{11)}$ はラットにギプス固定を行うと立ち上がり回数が 有意に減少すると同時に，ケージ内を移動する様子もあ まり観察されず，ギプス固定での関節の不動化に伴う痛 みによって活動性が低下することを報告している，本研 究ではそのような影響を除外するために，発痛物質に対 する鎮痛作用に有効であるとされる ${ }^{12)}$ ブプレノルフィン を処置後 5 日間すべての実験群に対し12時間ごとに皮下 投与 $(0.05 \mathrm{mg} / \mathrm{kg} \cdot$ body weight) した。 それにより，処 置の翌日から固定を施した群でも対照群と比べて活動性 に顕著な低下はみられなかった。また，固定期間中は毎 日, 経過観察を行い固定具の脱落や足部に浮腫が見られ た場合は適宜に再固定を行った。

関節可動域測定 関節可動域の測定はOno ${ }^{13)}$ の方法を 一部改良して実施した，処置前と固定終了時に足関節を 最大底屈させた状態と圧痛計（松宮医科精器製作所，手 動式皮膚痛覚計）を用いて足底中央部から押圧（約450 $\mathrm{mN}$ ） し足関節を背屈させた状態とをそれぞれデジタル カメラ (Canon, IXY DIGITAL 70) で撮影した。 その 画像をパーソナルコンピュータに取り込み，画像分析ソ フト（Scion Image ver.1.62）を用いて足関節の背屈可 動域を算出した。

筋張力測定 2 週間の固定期間終了後，全ての群に対 してペントバルビタールナトリウムを腹腔内投与（50 $\mathrm{mg} / \mathrm{kg} \cdot$ body weight）し，深麻酔をかけて実験に供し た．筋張力の測定は我々の以前の報告 ${ }^{14)}$ と同様の方法 で実施し，被検筋として右後肢のヒラメ筋（soleus； SOL）を摘出した後リンゲル液で満たしたマグヌス管 内で一端をクリップに，もう一端をアイソメトリックト ランスデューサ（日本光電, TB-651T）に連結して固 定した，管内の筋に対しプレート電極を介して電気刺 激装置（日本光電，SEN-3301）㘦電気刺激（1 msの

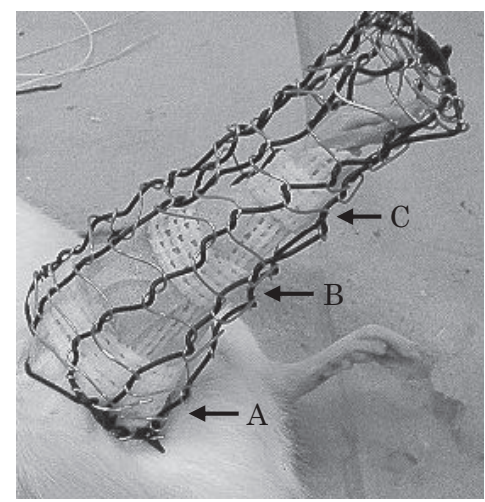

Fig 2. Appearance of the fixation

The affected hindlimb was fixed by a dorsal splint with connections to distal femur(A), distal leg(B) and foot(C), then was protected by a cover socket made of wires. 
矩形波）を与え, 最大単収縮張力が得られる至適筋長に 設定した。そして, 基礎医学研究用システム（日本光 電，LEG-1000）を用い，デジタルオシロスコープ上に 映し出された単収縮曲線から単収縮張力 (peak twitch force；PTF)，単収縮時間 (contraction time；CT)，1/2 弛緩時間（half relaxation time；HRT）を計測した。筋 張力測定後に至適筋長と筋湿重量を測定し，その値か らMendez $~^{15)}$ の式によって平均筋横断面積を求めて単 位断面積あたりの単収縮張力を算出した。その後, 摘 出した筋を組織化学標本用と生化学標本用とに二分し, それぞれを液体窒素で泠却したイソペンタン中で急速 凍結させた後, 使用するまで-80 $\mathrm{C}$ の超低温フリーザー （SANYO，MDF-192）内にて保管した.

組織化学分析 組織化学標本からは, $-20^{\circ} \mathrm{C}$ のクリオ スタット（Leica，CM1850）にて10um 厚の連続横断 切片を作製し、コハク酸脱水素酵素 (succinate dehydrogenase； SDH）染色とアルカリ前処理（pH 10.4）を 行ったミオシンアデノシンシリン酸分解酵素 (myosin adenosinetriphosphatase；ミオシンATPase）染色を実 施した。これら 2 種類の染色像を, 光学顕微鏡（Nikon, ECLIPSE 80i）を用いてパーソナルコンピュータに取 り込み，それらの画像をもとにSO (slow-twitch oxidative) 線維, FOG (fast-twitch oxidative glycolytic) 線 維, FG (fast-twitch glycolytic) 線維の 3 種類に分類し た上で，画像解析ソフト（Scion Image ver.1.62）を用 いて筋線維タイプ別横断面積を計測した。尚, ミオシ ンATPase染色像に扒いてセントラルコア損傷 (central core lesion；CCL）がみられた場合は，その本数率（200 倍の倍率で撮影された顕微鏡写真内の全筋線維数に対す るCCLがみられた筋線維数の割合) と面積率（CCLがみ られた筋線維の横断面積に対するCCL部分が占める面積 の割合）を求めた。また，同様にへマトキシリンーエオ ジン (hematoxylin-eosin；HE) 染色も実施した.

生化学分析 生化学標本からは, Doucetら ${ }^{16)}$ の方法に基 づいたドデシル硫酸ナトリウムポリアクリルアミドゲル 電気泳動法 (sodium dodecylsulfate polyacrylamide gel electrophoresis；SDS-PAGE）を用いて，ミオシン重 鎖（myosin heavy chain；MHC）を分離した。筋組織 を14〜25mgにトリミングしてからマイクロチューブ内 でホモジナイズし40倍の抽出液を作製した。そして，そ れをインキユベーション溶液にて75倍に希䣋したものを 1 レーンあたり $7.5 \mu \mathrm{l}$ 注入し, $4{ }^{\circ} \mathrm{C} て ゙ 170 \mathrm{~V} の$ 定電圧で 48 時間電気泳動を行った。電気泳動終了後に取り出され たゲル板に銀染色を施し，それぞれのバンド（MHC1， $2 \mathrm{a} ， 2 \mathrm{~d}, 2 \mathrm{~b}$ ）の濃度を画像解析ソフト（Scion Image ver.1.62）により計測した後, アイソフォーム構成比を
算出した.

統計学的処理 デー夕はすべて平均值土標準偏差で表し た。また，各群間の比較には一元配置分散分析を行った 上で多重比較検定はTukey法を用い，危険率 $5 \%$ 未満を 以って有意とした。

\section{結 果}

関節可動域 各群に打ける右足関節背屈可動域の変化を Fig 3 に示す。固定終了時ではその影響により有意に減 少し，骨折を伴うとさらに有意に減少した。

筋湿重量 各群における体重に対する筋湿重量の割合を Table 1に示す，固定の影響により有意に減少し，骨折 を伴うとさらに有意に減少した

筋張力特性 各群に打ける筋張力特性（単位断面積あた りのPTF, CT, HRT) をTable 2 に示す。単位断面積 あたりのPTFでは固定の影響により低下寸る傾向が見 られ，骨折を伴うとさらに有意に低下した。また，CT は骨折を伴うと有意に短縮したが，HRTでは有意な変 化がみられなかった。

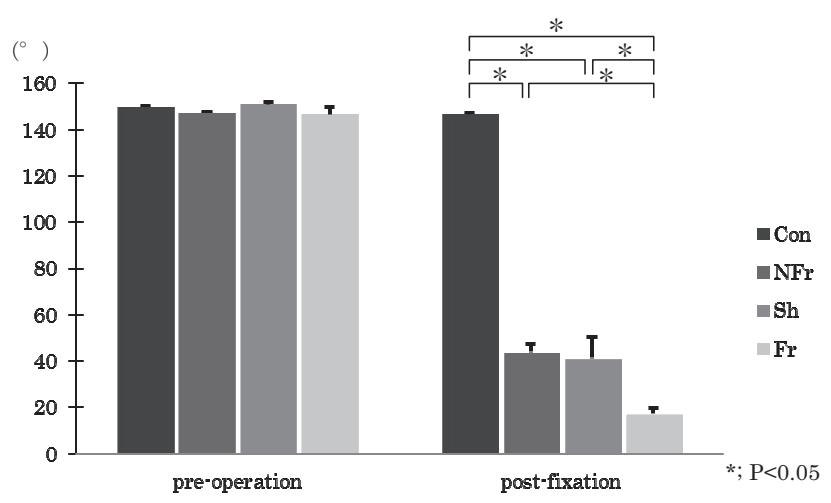

Fig 3. Range of motion at the right ankle joint

Table 1. Body weight and index of muscle atrophy

\begin{tabular}{|c|c|c|c|}
\hline & $\mathrm{BW}(\mathrm{g})$ & MW (mg) & MW to BW ratio \\
\hline Con & $300.9 \pm 20.0777$ & $116.4 \pm 8.0$ & $0.39 \pm 0.027 .7$ \\
\hline NFr & $213.6 \pm 20.8$ & $52.4 \pm 11.1$ & $0.25 \pm 0.07]^{n}$ \\
\hline $\mathrm{Sh}$ & $225.9 \pm 6.8$ & $57.3 \pm 8.2$ & $0.25 \pm 0.03$ \\
\hline $\mathrm{Fr}$ & $236.5 \pm 3.3$ & $37.2 \pm 5.3$ ]踏 & $0.16 \pm 0.02\rfloor]$ \\
\hline
\end{tabular}

Table 2. Muscle contractile properties

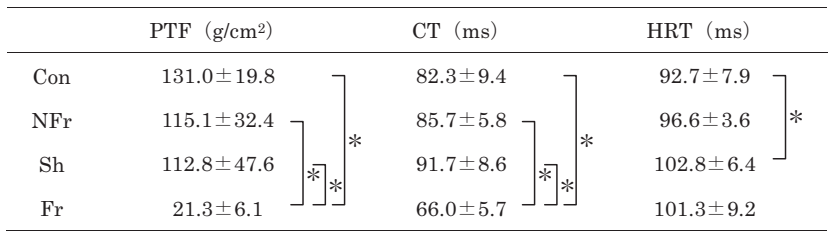


筋形態特性 各群における筋線維タイプ別横断面積を Fig 4 に, CCL像とその発生率をFig 5, Table 3 にそれ ぞれ示す.

笳線維タイプ別横断面積 固定の影響によりSO線維並 びにFOG線維はともに有意に減少した。また，骨折を 伴うとSO線維ではさらに有意に減少したが, FOG線維 では有意な変化がみられなかった。尚，すべての群にお いてFG線維の存在は認められなかった。

CCL発生率 固定の影響により発生が認められ, 骨折 を伴うとその本数率並びに面積率はともに有意に増加し た。

MHCアイソフォーム構成 各群におけるMHCアイソ フォームの分離像とその構成比をFig 6, Table 4 に それぞれ示す。固定の影響により MHC1の減少傾向と

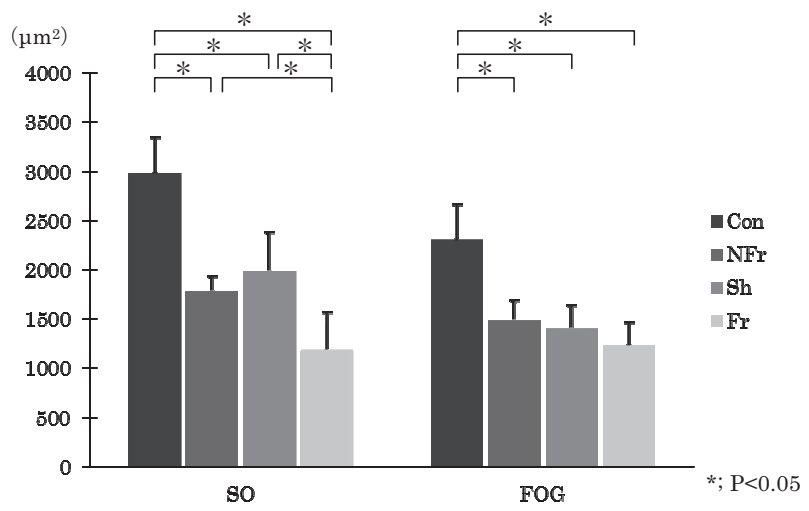

Fig 4. Muscle fiber cross sectional area

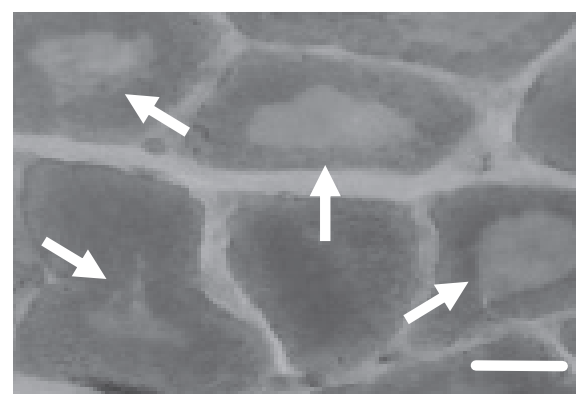

Fig 5. CCL in alkali-preincubated myofibrillar ATPase staining

The CCL (arrows) indicated as a defocused area at the center of a muscle fiber appeared in the NFr group, and increased in the Fr group particularly. scale bar $=25 \mu \mathrm{m}$

Table 3. Incidence of CCL (\%)

\begin{tabular}{|c|c|c|}
\hline & count ratio & area ratio \\
\hline Con & 0 & 0 \\
\hline NFr & $15.3 \pm 4.7$ & $14.5 \pm 3.1$ \\
\hline Sh & $15.8 \pm 8.2$ * & $15.4 \pm 3.8$ \\
\hline $\mathrm{Fr}$ & $29.8 \pm 19.7-\sqcup$ & $30.8 \pm 13.3$ \\
\hline
\end{tabular}

MHC2dの有意な増加がみられた。 また, 骨折を伴うと MHC1の有意な減少とMHC2aの増加傾向がみられた。

\section{考察}

本実験モデルの妥当性 増田ら ${ }^{17)}$ はラットの脛骨を人為 的に骨折させ, その 2 週間後に単純 X線像により骨折部 を確認したところ，明らかな仮骨形成が観察できたと報 告している. 本研究では, 固定期間終了後にmicro CT (日 立メディコ社，CBSTAR MCT-100CB）を用いて骨折 部を確認したところ, 仮骨形成を認め, 且つ際立った骨 の再転位もみられなかった。つまり, 今回用いた外固定 は患部に適切な治癒過程を認めたことから妥当な方法で あったと考えられる。また，すべての実験結果において 外固定のみを行ったNFr群と偽手術と外固定を行ったSh 群において有意な差が認められなかったことから，外科 手術においても周囲の骨格筋への侵襲を最小限に抑えた 方法であったといえる。

関節可動域制限 Okitaら ${ }^{10)}$ はラットの足関節を最大底 屈位で 2 週間ギプス固定すると平均 $50.2^{\circ}$ の可動域制限 が認められたとし，岡本ら ${ }^{18)} も$ 同様の実験において平均 $54.0^{\circ}$ の可動域制限がみられたと報告している。本研究 において, NFr群では平均 $102.7^{\circ}$ の可動域制限が確認で きたが，この值は先行研究と比較するとかなり大きなも のとなっていた。 この原因としては, 固定材料が歯み切 られるのを防ぐために装着したソケット状の金具の影響 が考えられる。この金具を患側下肢全体に被せたことに より，固定期間中の移動の際には足趾が床に接地せず, 患側肢にかかる体重負荷を金具で支えることになり，結 果的に免荷歩行の効果があったものと推察される。関節 固定に後肢懸垂による免荷を加えたこれまでの研究で は, 足関節の可動域制限が固定のみの時よりも著しく増 大する $\left(\right.$ 平均 $\left.89.4^{\circ}\right)$ ことが報告されており ${ }^{19)}$, 本研究

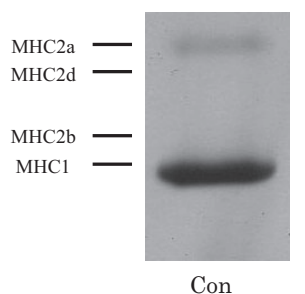

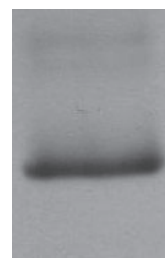

NFr

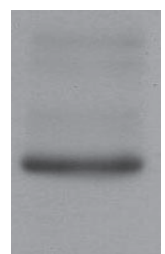

$\mathrm{Sh}$

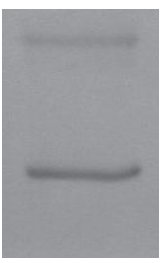

$\mathrm{Fr}$
Fig 6. Separate phases of MHC isoforms by SDS-PAGE

Table 4. Relative ratio of MHC isoforms

\begin{tabular}{|c|c|c|c|c|}
\hline & MHC1 & MHC2a & MHC2d & MHC2b \\
\hline Con & $87.9 \pm 2.7$ & $12.1 \pm 2.7$ & 屈] & 0 \\
\hline NFr & $79.4 \pm 6.7$ & $15.9 \pm 6.8$ & $4.7 \pm 1.2^{]^{\top}} \mid *$ & 0 \\
\hline Sh & $80.1 \pm 7.5$ & $13.8 \pm 8.4$ & $4.5 \pm 0.6$ & $1.7 \pm 3.3$ \\
\hline $\mathrm{Fr}$ & $60.7 \pm 13.1$ & $33.0 \pm 7.2$ & $6.3 \pm 7.3$ & 0 \\
\hline
\end{tabular}


の結果もそれに近いものであった。また，Fr群では平 均 $129.2^{\circ}$ の可動域制限が認められたが, 以下に述べるよ うに骨折を伴うことで足関節の底屈筋であるSOLの筋萎 縮がさらに進行し, その結果, 足関節の背屈可動域制限 を増大させたものと考えられる。

廃用性筋萎縮 本研究において短縮位での固定となっ たSOLでは，体重に対する筋湿重量の割合がCon群と比 較するとNFr群では平均 $35.9 \%$ 減少し, Fr群では平均 59.0\%減少していた。これまでの研究では, 骨格筋は短 縮位で不動化されることで筋線維径が縮小し, 筋タンパ ク量が減少するため筋湿重量も減少する ${ }^{20)}$ 一方で, 伸長 位で不動化されると筋に作用する張力の刺激により筋夕 ンパクの合成が促進されるため筋肥大が起こるとされて いる ${ }^{21)}$. さらに, 近年の研究ではこのような骨格筋の可 塑性に対して, 炎症性サイトカインであるインターロイ キン6（interleukin-6；IL-6） や腫瘍壊死因子 $\alpha$ （tumor necrosis factor $-\alpha$; TNF- $\alpha$ ) の筋タンパク分解促進作 用や, 線維芽細胞成長因子 (fibroblast growth factor ; FGF）やインスリン様成長因子（insulin-like growth factor； IGF）の筋タンパク合成促進作用が注目されて いる ${ }^{22-25)}$. 宮井ら ${ }^{26)}$ は, マウスの骨折モデルで術後の炎 症性サイトカインの血中濃度が有意に上昇すると報告し ていることから, 本研究においても，Fr群では炎症性 サイトカインの影響により筋萎縮がさらに進行したので はないかと考えられる

また，筋線維タイプ別横断面積について, Con群と比 較するとNFr群ではSO線維で平均 $39.7 \%, \mathrm{FOG}$ 線維で平 均 $34.9 \%$ 減少し, Fr群ではSO線維で平均 $60.1 \%, F O G$ 線 維で平均 $46.2 \%$ 減少する結果となり, 骨折を伴うとFOG 線維よりもSO線維の方で選択的に筋萎縮が進行するこ

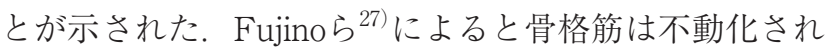
ると, 毛細血管-筋線維比や血管径が減少するが, それ により筋線維への血流量も減少し, 酸素や栄養素の供給 低下を招くとされている。また，彼らは毛細血管からの 酸素供給に強く依存する有酸素ATP合成系（クエン酸 回路）の方が, 無酸素ATP合成系（解糖系）よりも不 動化の影響が大きいことも報告している ${ }^{28)}$. このことか ら, 筋線維の血流量減少により有酸素ATP合成の場で あるミトコンドリアを多く含む筋線維 ( $\mathrm{SO}$ 線維) でそ の機能性が低下し, 選択的に筋萎縮が進行する原因に なったものと推察される.

筋細胞壊死 CCLは, 免荷や不動化に伴って筋細胞内 の $\mathrm{Ca}^{2+}$ の濃度が上昇し, それによって活性化された カルシウム活性プロテアーゼ（カルパイン）による筋 原線維の破壊を示すもので29), その部分ではミオシン ATPase活性が低下しているため, ミオシンATPase染
色では周囲よりも淡く染め出される. 本研究で，ミオシ ンATPase染色像において筋線維の中心部が周辺部より も淡染しているものをCCLとしてその発生率を求めたと ころ，NFr群でその発生が認められ，Fr群ではその率が 約 2 倍に上昇していた。CCLは短縮位固定で発生が促進 され，伸長位固定では抑制されること ${ }^{30)}$ や，主にtype I （SO）線維で発生すること ${ }^{31)}$ など報告されている。ま た，本研究のHE染色像において「筋線維の小径化と間 質結合組織の増加」「貪食細胞の浸潤と細胞壊死像」と いった病理的所見が固定を行った 3 群で認められ，好塩 基性の胞体や中心核といった筋の再生過程を表す細胞像 についてはFr群で多くみられた（Fig 7).

以上のような笳細胞の壊死は, FGFやIGFなどの成長 因子の分泌低下, $\mathrm{TNF}-\alpha$ による筋タンパク分解, カル パイン活性による酸化ストレスが引き起こす熱ショック タンパク（heat shock protein；HSP）の低下などが促 進する要因として報告されている32-35)。ささらに, このよ うな要因は骨格筋に対する機械的ストレスが低下するこ とで惹き起こされると考えられているが，骨折がこれら に対してどのような影響を及ぼしているのかは現在のと ころ明らかになっていない，ただし，筋萎縮の進行と同 様に骨折の影響によりこれらの要因が増強され，筋細胞 の壊死が進行している可能性も充分に予想される.

筋収縮タンパクと筋張力特性 成熟したラットの骨格 筋におけるMHCアイソフォームは，1つのslow type myosin (MHC1) と 3 つ fast type myosin (MHC2a, $2 \mathrm{~d}, 2 \mathrm{~b})$ から構成されており, 夕イプ移行する場合 は $\mathrm{MHCl} \Leftrightarrow 2 \mathrm{a} \Leftrightarrow 2 \mathrm{~d} \Leftrightarrow 2 \mathrm{~b}$ と段階的に移行するとされてい る36)。これまでの研究では，萎縮したSOLではMHC1の 相対的な減少と MHC2dの発現がみられることが報告さ れており ${ }^{8)}$ ，本研究においても，固定に骨折の影響が加 わるに従ってMHC1の減少と MHC2aの増加, MHC2dの 新たな発現が認められたことから, 先行研究と同様に, 筋萎縮によってMHCアイソフォームはslow typeから fast typeへと移行し，速筋化することが示された。この ようなMHCアイソフォームの変化は, 筋線維の横断面
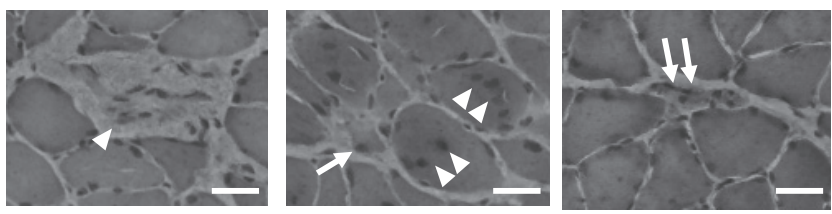

Fig 7. HE staining of the cross section of Fr group soleus muscle

Features of muscle atrophy (arrowhead, necrotic cell; arrow, shrunken cell) and regeneration (double arrowheads, centrally located nuclei; double arrows, basophilic matrix) were prominently found.

scale bar $=25 \mu \mathrm{m}$ 
積が変化することに影響を受けるとされる SO線維の横断面積減少がslow type myosinの減少に関 係しているものと考えられる.

次に，本研究における単位断面積あたりのPTFにつ いて, Con群と比較するとNFr群では平均 $12.1 \%$ 低下し, Fr群では平均 $83.7 \%$ の大幅な低下が認められた。このよ うな収縮張力の低下には, 筋線維横断面積の減少だけで なく, 筋膜の肥厚や筋節構造の乱れなどその他の形態特 性の変化も影響しているものと考えられるが，骨折を伴 うことでその影響がより大きくなったものと推察でき る。

また，固定に骨折の影響が加わるに従ってCTは短縮 傾向を示したが，これには単位断面積あたりのPTFの 低下による収縮時間の短縮やMHCの速筋化による収縮 速度の増加が影響したものと考えられる。一方, HRT では有意な変化がみられなかったことから，筋の弛緩時 には収縮時とは異なる要素が関与しているのではないか

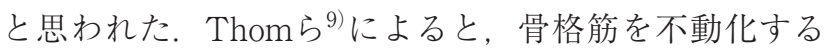
ことで筋小胞体の $\mathrm{Ca}^{2+}$ ポンプ機能が低下するとされて いる。つまり，萎縮した筋ではカルパインの作用により 筋小胞体の破壊が進むため, 全体としてC ${ }^{2+}$ を取り込 む能力が低下し，過収縮状態となって弛緩しにくくなっ ていると考えられる。よって, HRTは単位断面積あた りのPTFの低下やMHCの速筋化によりCTと同様に短縮 するであろうと思われたが，この期待された短縮が筋小 胞体の変性による弛緩過程の延長によって打ち消された ために，見かけ上の変化は現れなかったものと推察され る.

今後の課題 近年, 骨格筋の廃用性筋萎縮を進行させる 様々な要因については研究が進み, 徐々に解明されつつ ある。しかし，骨折による影響については依然として不 明な点が多い. 本研究からは骨折が不動化が惹き起こす 要因を助長している可能性が示唆されたが，今後はその 可能性を詳細に検討するため, さらに研究を進める必要 があると考える。

\section{参 考 文 献}

1）石井光昭: 関節拘縮, 理学療法ハンドブック 第 1 巻 理 学療法の基礎之評価, 改訂第 3 版, 細田多穂, 柳澤 健, 東 京: 協同医書出版社, 333-349, 2006.

2) Trudel G and Uhthoff HK: Contractures secondary to immobility: Is the restriction articular or muscular? An experimental longitudinal study in the rat knee. Arch Phys Med Rehabil 81: 6-13, 2000.

3) Moriyama H, Yoshimura O, Sunahori $\mathrm{H}$ and Tobimatsu Y: Comparison of muscular and articular factors in the progression of contractures after spinal cord injury in rats. Spinal Cord 44: 174-181, 2006.

4) Fujita N, Fujimoto T, Tasaki H, Arakawa T, Mat- subara $\mathrm{T}$ and Miki A: Influence of muscle length on muscle atrophy in the mouse tibialis anterior and soleus muscles. Biomed Res 30: 39-45, 2009.

5) Williams PE: Effect of intermittent stretch on immobilized muscle. Ann Rheum Dis 47: 1014-1016, 1988.

6) Gomes AR, Coutinho EL, Franca CN, Polonio J and Salvini TF: Effect of one stretch a week applied to the immobilized soleus muscle on rat muscle fiber morphology. Braz J Med Biol Res, 37: 1473-1480, 2004.

7）沖田 実: 関節可動域制限の病態生理, 理学療法, 20: 603-611, 2003.

8) Zhong H, Roy RR, Siengthai B and Edgerton VR: Effects of inactivity on fiber size and myonuclear number in rat soleus muscle. J Appl Physiol 99: 1494-1499, 2005.

9) Thom JM, Thompson MW, Ruell PA, Bryant GJ, Fonda JS, Harmer AR, De Jonge XA and Hunter SK: Effect of 10-day cast immobilization on sarcoplasmic reticulum calcium regulation in humans. Acta Physiol Scand 172: 141-147, 2001.

10) Okita M, Yoshimura T, Nakano J, Motomura M and Eguchi K: Effects of reduced joint mobility on sarcomere length, collagen fibril arrangement in the endomysium, and hyaluronan in rat soleus muscle. $J$ Muscle Res Cell Motil 25: 159-166, 2004.

11）山本 綾, 古島泰子, 長谷川多美子, 肥田朋子: ラット足 関節不動化による活動制限は痛みを促進する, 理学療 法学 36: 305-311, 2009.

12）窪田一史: 新生ラット鎮痛試験法 - 発痛物質誘発体動 の定量 -, 日本薬理学雑誌 115: 345-351, 2000.

13) Ono T, Miyoshi M, Oki S, Shimizu ME, Umei N, Shiraiwa $\mathrm{K}$, Takemoto $\mathrm{H}$, Shimatani $\mathrm{K}$, Hasegawa $\mathrm{M}$ and Otsuka A: The effect of ROM exercise on rats with denervation and joint contracture. J Phys Ther Sci 21: 173-176, 2009.

14）今北英高, 小野志操, 麦田盛穂, 峯松 亮, 西尾俊亮, 西川 彰, 宮田浩文: ラット横隔膜における機能特性㧍よび形 態特性の加齢変化, 総合リハビリテーション 38: 865871, 2010.

15) Mendez A and Keys A: Density and composition of mammalian muscle. Metabol 9: 184-188, 1960.

16) Doucet JP and Trifaro JM: A discontinuous and highly porous sodium dodecyl sulfate-polyacrylamide slab gel system of high resolution. Anal Biochem 168: 265271, 1988 .

17）増田雅保, 田口大輔, 竹内義享：骨折に扮けるX線像 と超音波観察の比較, 柔道整復接骨医学 16: 163-166, 2008.

18）岡本眞須美, 沖田 実, 加須屋茜, 中野治郎, 鍬塚幸子, 西 田まどか, 友利幸之介, 吉村俊朗: 不動期間の延長に伴 うラット足関節可動域の制限因子の変化一軟部組織 （皮膚・筋）と関節構成体由来の制限因子について-, 理学療法学 31: 36-42, 2004.

19）西田まどか, 沖田 実, 福田幸子, 岡本眞須美, 中野治郎, 友利幸之助, 吉村俊朗: 持続的伸張運動と間歇的伸張運 動が拘縮と筋線維に及ぼす影響－関節固定法と後肢懸 垂法を組み合わせたラットの実験モデルによる検討一, 理学療法学 31: 304-311, 2004. 
20) Williams PE and Goldspink G: Connective tissue changes in immobilized muscle. J Anat 138: 343-350, 1984.

21) Goldspink DF: The influence of immobilization and stretch on protein turnover of rat skeletal muscle. $J$ Physiol 264: 267-282, 1977.

22) Shephard RJ: Cytokine responses to physical activity, with particular reference to IL-6: sources, actions, and clinical implications. Crit Rev Immunol 22: 165-182, 2002.

23) Coletti D, Moresi V, Adamo S, Molinaro M and Sassoon D: Tumor necrosis factor-alpha gene transfer induces cachexia and inhibits muscle regeneration. Genesis 43: 120-128, 2005.

24) Yamada S, Buffinger N, DiMario J and Strohman RC: Fibroblast growth factor is stored in fiber extracellular matrix and plays a role in regulating muscle hypertrophy. Med Sci Sports Exerc 5: 173-180, 1989.

25) Loughna PT, Mason P and Bates PC: Regulation of insulin-like growth factor 1 gene expression in skeletal muscle. Symp Soc Exp Biol 46: 319-330, 1992.

26）宮井崇宏, 荒井千明, 玉澤 学, 奈須純一, 富永徳子, 小俣 和彦, 宮坂孝弘, 松野智宣, 佐藤田鶴子: 実験的マウス骨 折モデルにおける血中サイトカインの変化に関する検 討, 歯薬療法 26: 9-13, 2007.

27) Fujino H, Kohzuki H, Takeda I, Kiyooka T, Miyasaka T, Mohri S, Shimizu J and Kajiya F: Regression of capillary network in atrophied soleus muscle induced by hindlimb unweighting. J Appl Physiol 98: 14071413, 2005.

28）藤野英己, 上月久治, 武田 功, 笹井宣昌, 村上慎一郎, 村 田 伸, 石井禎基, 松永秀俊, 石原昭彦, 梶谷文彦: 廃用性 萎縮筋における毛細血管リモデリングと血管増殖因子 の抑制, 理学療法科学 23: 203-208, 2008.

29) Riley DA, Slocum GR, Bain JL, Sedlak FR, Sowa TE and Mellender JW: Rat hindlimb unloading: soleus histochemistry, ultrastructure, and electromyography. J Appl Physiol 69: 58-66, 1990.

30) Baewer DV, Hoffman M, Romatowski JG, Bain JL, Fitts RH and Riley DA: Passive stretch inhibits central corelike lesion formation in the soleus muscles of hindlimb-suspended unloaded rats. J Appl Physiol 97: 930-934, 2004

31) Murakami T, Hijikata $\mathrm{T}$ and Yorifuji H: Staging of disuse atrophy of skeletal muscles on immunofluorescence microscopy. Anat Sci Int 83: 68-76, 2008.

32) Eash J, Olsen A, Breur G, Gerrard D and Hannon K: FGFR1 inhibits skeletal muscle atrophy associated with hindlimb suspension. BMC Musculoskelet Disord 8: 2007.

33) Litvinova KS, Tarakin PP, Fokina NM, Istomina VE, Larina IM and Shenkman BS: Reloading of rat soleus after hindlimb unloading and serum insulin-like growth factor 1. Ross Fiziol Zh Im I M Sechenova 93: 1143-1155, 2007.

34) Hirose $T$, Nakazato $K$, Song $H$ and Ishii $N$ : TGF- $\beta_{1}$ and $\mathrm{TNF}-\alpha$ are involved in the transcription of type I collagen $\alpha_{2}$ gene in soleus muscle atrophied by mechanical unloading. J Appl Physiol 104: 170-177, 2008.

35) Naito H, Powers SK, Demirel HA, Sugiura T, Dodd SL and Aoki J: Heat stress attenuates skeletal muscle atrophy in hindlimb-unweighted rats. J Appl Physiol 88: 359-363, 2000.

36) Pette D and Staron RS: Transitions of muscle fiber phenotypic profiles. Histochem Cell Biol 115: 359-372, 2001.

37）山内秀樹, 刈谷文彦, 田端淳一, 宮野佐年: 成熟ラット速 筋の形態ならびにミオシン重鎖分子種組成に及ぼす長 期非荷重の影響, 日本生理学会 64: 147-151, 2002. 